\title{
SURVEI PENGELOLAAN EKSTRAKURIKULER OLAHRAGA SEKOLAH DASAR NEGERI KOTA TARAKAN
}

\author{
Sucahyo Mas'an Al wahid ${ }^{1}$, Hegen Dadang Prayoga ${ }^{2}$ \\ Universitas Borneo Tarakan (Indonesia) ${ }^{1}$ \\ Universitas Islam Kalimantan Muhammad Arsyad Al-Banjari (Indonesia) ${ }^{2}$ \\ E-mail:cahyowahid@gmail.com
}

\begin{abstract}
ABSTRAK
Satuan pendidikan menyediakan wadah kegiatan ekstrakurikuler olahraga untuk menyalurkan bakat, minat, hobi kepribadian dan kreativitas peserta didik yang dapat dijadikan sebagai alat pendeteksi talenta peserta didik dan desain secara profesional sehingga dapat menjadi wahana dalam melahirkan bakat, membentuk karakter, dan tempat aktualisasi peserta didik. Tujuan pelaksanaan penelitian yaitu mengetahui pengelolaan ekstrakurikuler olahraga yang ada di sekolah dasar negeri kota tarakan, metode yang digunakan analisis survei berupa deskriptif kuantilatif, serta hasil yang diperoleh bahwa sekolah dasar negeri 023 dan 024 mendapatkan kategori sangat baik sebesar 90\% pengelolaan ekstrakurikuler olahraga yang dilaksanakan, sekolah dasar negeri 006, 031, 032,036 mendapat kategori baik dengan hasil presentase sebesar 76\%, sedangkan pada sekolah dasar 016 kategori cukup dengan besar presentase 50\% sehingga dapat ditarik kesimpulan bahwa sekolah dasar negeri 023 dan 024 dapat menjadi piloting projek pengelolaan ekstrakurikuler olahraga namun pada sekolah dasar 016 dapat menjadi pecutan untuk mengelola sesuai kebutuhan yang ada disekolah dan berdasarkan pernyataan pada setiap fungsi kegiatan pengelolaan ekstrakurikuler.
\end{abstract}

Kata Kunci: Survei, Pengelolaan, Estrakurikuler Olahraga, Sekolah Dasar

\begin{abstract}
The education unit provides a forum for ekstrakurikuler activities to channel the talents, interests, personality hobbies and creativity of students which can be used as a tool to detect students' talents and design them professionally so that they can be a vehicle for producing talents, shaping character, and a place for students to actualize. The purpose of the research was to determine the management of extracurricular activities in public elementary schools of Tarakan city, the method used in the survey analysis was quantilatif descriptif, and the results obtained were that the 023 and 024 public elementary schools received very good categories of $90 \%$ of ekstrakurikuler management implemented, elementary schools. country 006, 031, 032, 036 got a good category with a percentage result of $76 \%$, while in elementary school 016 the category was sufficient with a large percentage of $50 \%$ so it can be concluded that public elementary schools 023 and 024 can be piloting ekstrakurikuler management projects but in schools Basic 016 can be a fringe to manage according to the needs of the school and based on statements on each function of ekstrakurikuler management activities.
\end{abstract}

Keywords: Survey, Management, Sport Ekstrakurikuler, Elementary School

Dipublikasikan Oleh :

UPT Publikasi dan Pengelolaan Jurnal

Universitas Islam Kalimantan Muhammad Arsyad Al-Banjari Banjarmasin 


\section{PENDAHULUAN}

Satuan pendidikan menyediakan wadah kegiatan ekstrakurikuler untuk menyalurkan bakat, minat, hobi kepribadian dan kreativitas peserta didik yang dapat dijadikan sebagai alat pendeteksi talenta peserta didik dan desain secara profesional sehingga dapat menjadi wahana dalam melahirkan bakat, membentuk karakter, dan tempat aktualisasi peserta didik. Karakter peserta didik juga terlihat ketika mengikuti kegiatan ekstrakurikuler meskipun abstrak untuk di ukur dalam bentuk matematis namun terwujud dengan sendirinya keterampilan yang dimiiki ketika berpendapat ditempat umum dan bekerjasama dalam kelompok (Sayidah dkk:2014). Namun hal ini tidak sejalan dengan pengelolaan ekstrakurikuler olahraga yang dilaksanakan di sekolah berdasarkan observasi yang ditemukan mahasiswa praktek pengalaman lapangan terdapat perbedaan yang signifikan pada fungsi perencanaan, sekitar $60 \%$ sekolah dasar di kota tarakan merubah kegiatan yang sudah ada menjadi kegiatan baru pada tahun berikutnya sesuai kebutuhan peserta didik. Tidak sejalan dengan pendapat Tarbiyah dkk (2019) yang menyatakan tahap perencanaan dapat dilaksanakan dan ditiadakan sesuai hasil evaluasi kegiatan setiap satu bulan atau satu semester. Pada fungsi pengorganisasian, sekitar $30 \%$ sekolah belum terdapat struktur organisasi kepengurusan kegiatan ekstrakurikuler yang dapat dibuktikan. Pada fungsi staffing potensi kekhawatiran sekolah sebesar 70\% dikarenakan minimnya pelatih yang sesuai bidang kegiatan ekstrakurikuler sehingga menunjuk langsung warga sekolah. Pada fungsi pengarahan dan pengkoordinasian sekitar $20 \%$ manajemen yang berjalan kurang baik selebihnya sesuai dengan harapan. Berdasarkan pendapat M. Marzuan (2018) proses kemajuan peserta didik dapat ditunjukkan melalui nilai evaluasi kegiatan oleh pembina ekstrakurikuler dan dapat dikomunikasikan kepada kepala sekolah untuk dibijaki pada kegiatan selanjutnya agar saling terkoneksi dan sesuai tata kelola organisasi. Fungsi pengganggaran $80 \%$ sekolah mendapatkan dari anggaran pribadi pembina dan wali murid, sedangkan fungsi penyusunan laporan $90 \%$ kegiatan ekstrakurikuler di sekolah lebih dominan terlaksana pada agenda class meeting. Dapat digarisbawahi tujuan dari penelitian ini untuk mengetahui sistem pengelolaan dan pengembangan kegiatan ektrakurikuler olahraga pada sekolah dasar di kota tarakan.

\section{METODE}

Jenis penelitian kuantilatif yaitu suatu penelitian yang bertujuan mendapatkan gambaran atau kenyataan sesungguhnya suatu objek yang didukung oleh data-data jawaban dari responden. Sumber data hasil observasi mahasiswa PPL, instrumen pengumpulan data melalui angket dan wawancara tidak terstruktur tanpa melakukan pengujian hipotesis. Metode yang digunakan berupa survei dan objek tentang pengelolaan ekstrakurikuler terdiri dari 7 sampel sekolah yang mewakili dari masing-masing gugus. Kemudian data di analisis berupa deskripsi tabel berdasarkan hasil angket modifikasi Pramudito (2016) berupa skala likert 1-4 dan subjek penelitian guru pembina ekstrakurikuler.

\section{HASIL DAN PEMBAHASAN}

Pengambilan data dilaksanakan pada tahun 2018 oleh mahasiswa pada matakuliah pengelolaan kegiatan ekstrakurikuler. Adapun 7 sekolah yang menjadi sampel penelitan :

\begin{tabular}{|c|l|l|}
\hline No & \multicolumn{1}{|c|}{ Nama Sekolah } & \multicolumn{1}{|c|}{ Pembina } \\
\hline 1 & SD NEGERI 032 Tarakan & JN \\
\hline 2 & SD NEGERI 006 Tarakan & ST dan MMS \\
\hline 3 & SD NEGERI 036 Tarakan & T \\
\hline 4 & SD NEGERI 024 Tarakan & FCS \\
\hline 5 & SD NEGERI 031 Tarakan & R \\
\hline 6 & SD NEGERI 016 Tarakan & F \\
\hline 7 & SD NEGERI 023 Tarakan & NQ \\
\hline
\end{tabular}

Tabel 1. subjek penelitian

Dipublikasikan Oleh : 
Berdasarkan data tabel dapat dideskripsikan bahwa pembina ekstrakurikuler pada sekolah SDN 032 merupakan guru ekstrakurikuler, pembina pada sekolah 006 dan SDN 031 adalah guru olahraga, pembina pada SDN 036 sebagai penjaga sekolah, pembina sekolah SDN 024, SDN 023 dan SDN 016 merangkap sebagai guru kelas. Penguatan pada prestasi olahraga di sekolah pada kegiatan ekstrakurikuler yang direncanakan dan evaluasi oleh pembina berpendidikan olahraga pernyataan Wandi (2013)

\begin{tabular}{|l|l|l|}
\hline \multicolumn{1}{|c|}{ Nama Sekolah } & Presentase & \multicolumn{1}{c|}{ Nilai } \\
\hline SD NEGERI 024 & 77.5 & sangat baik \\
\hline SD NEGERI 006 & 87.5 & sangat baik \\
\hline SD NEGERI 032 & 87.5 & sangat baik \\
\hline SD NEGERI 016 & 70.0 & baik \\
\hline SD NEGERI 036 & 80.0 & sangat baik \\
\hline SD NEGERI 023 & 87.5 & sangat baik \\
\hline SD NEGERI 031 & 75.0 & baik \\
\hline
\end{tabular}

Tabel 2. fungsi perencanaan

Deskripsi terkait fungsi perencanaan pada sekolah dasar negeri 016 pada pernyataan sekolah merencanakan kepengurusan ekstrakurikuler, perencanaan anggaran dalam kegiatan ekstrakurikuler, merencanakan menerima peserta ekstrakurikuler, merencanakan cara penerimaan peserta, merencanakan kebutuhan pelatih, merencanakan program latihan, merencanakan waktu dan tempat kegiatan, membuat jurnal perkembangan peserta terdapat pilihan centang oleh guru kelas sering(SR) atau skala poin 3 dan memilih sekolah merencanakan pengadaan sarana dan prasarana yang dibutuhkan dan yang mendukung pada skala poin 2 atau kadang-kadang (K). kemudian pada sekolah dasar negeri 023 sekolah merencanakan kepengurusan, merencanakan pengadaan prasarana dan prasarana yang dibutuhkan dan mendukung, melakukan perencanaan anggaran, kebutuhan pelatih, program latihan, waktu dan tempat latihan mencentang selalu (S) atau skala poin 4, mencentang skala poin 3 atau sering (SR) pada pernyataan penerimaan peserta ekstrakurikuler, serta mencentang skala poin 2 atau kadang-kadang (K) pada pernyataan merencanakan cara penerimaan peserta ekstrakurikuler dan membuat jurnal perkembangan bakat. Berdasarkan pula pendapat oleh Bangun (2019) kematangan suatu prestasi pada kegiatan ekstrakurikuler olahraga sesuai pada perencanaan minat dan bakat pada siswa itu sendiri dengan penyeleksian sesuai kebutuhan.

\begin{tabular}{|l|l|l|}
\hline \multicolumn{1}{|c|}{ Nama Sekolah } & \multicolumn{1}{c|}{ Presentase } & \multicolumn{1}{c|}{ Nilai } \\
\hline SD NEGERI 024 & 96.4 & sangat baik \\
\hline SD NEGERI 006 & 67.8 & baik \\
\hline SD NEGERI 032 & 82.1 & sangat baik \\
\hline SD NEGERI 016 & 57.1 & baik \\
\hline SD NEGERI 036 & 60.7 & baik \\
\hline SD NEGERI 023 & 96.4 & sangat baik \\
\hline SD NEGERI 031 & 60.7 & baik \\
\hline
\end{tabular}

Tabel 3. fungsi pengorganisasian

Berdasarkan tabel fungsi pengorganisasian terdapat hasil pilihan dari guru kelas sekolah dasar negeri 016 pada angket mengorganisasi program sesuai perencaaan dan mengorganisasi sarana dan prasarana denga tepat pada skala poin 3 yaitu sering (SR), sedangkn pada aspek merencanakan organisasi kepengurusan, pembina melaksanakan tugas sesuai program, mensosialisasikan program kepada pihak yang terkait dan merekrut platih baru sesuai kualifikasi kebutuhan mendpatkan poin 2 kadang-kadang (K). kemudian pada skolh dasar negeri 024 pada pernyataan merencnakan struktur organisasi, pebina melaksanaka tugas sesuai tupoksi, mensosialisasikan program, mengorganisasi program, mengorganisasi sarana dan prasarana dengan tepat, mengaakn pertemuan dengan pelatih kesluruhan mendapatkan poin 4 atau centangan pada kat selalu (S), namun pada aspek merekrut pelatih baru jatuh pada poin 3 atau kegiatan sering (SR) dilakukan.

Dipublikasikan Oleh :

UPT Publikasi dan Pengelolaan Jurnal

Universitas Islam Kalimantan Muhammad Arsyad Al-Banjari Banjarmasin 


\begin{tabular}{|l|l|l|}
\hline Nama Sekolah & Presentase & Nilai \\
\hline SD NEGERI 024 & 100.0 & sangat baik \\
\hline SD NEGERI 006 & 70.0 & baik \\
\hline SD NEGERI 032 & 60.0 & baik \\
\hline SD NEGERI 016 & 70.0 & baik \\
\hline SD NEGERI 036 & 55.0 & baik \\
\hline SD NEGERI 023 & 100.0 & sangat baik \\
\hline SD NEGERI 031 & 50.0 & cukup \\
\hline
\end{tabular}

Tabel 4. fungsi staffing

Penjelasan daripada tabel meberikan informasi pada sekolah dasar negeri 023 pada pernyataan ikut membantu menyusun personalia, membentuk humas, kegatan kesekretariatan dibantu oleh staff, menjadwalkan keperluan hrian, mingguan dan bulanan, serta melakukan pembinaan dan mendampingi kegiatan pada poin 4 dan nampak pula pada sekolah dasar negeri 031 pada tahap pendampingan pembinaan dalam pencpaian prestasi mencentang sering (SR), ikut membantu menyusun personalia, kegiatn keseketariatan dan menjadwalkan alokasi kebutuhan harian, mingguan, bulanan trdapat centangan pada jawaban kadang-kadang, sehingga pada peryataan terakhir pembentukan humas mendapatkan poin 1 atau tidak pernah (TP).

\begin{tabular}{|l|l|l|}
\hline Nama Sekolah & Presentase & Nilai \\
\hline SD NEGERI 024 & 91.6 & sangat baik \\
\hline SD NEGERI 006 & 58.3 & baik \\
\hline SD NEGERI 032 & 66.7 & baik \\
\hline SD NEGERI 016 & 58.3 & baik \\
\hline SD NEGERI 036 & 83.3 & baik \\
\hline SD NEGERI 023 & 91.6 & sangat baik \\
\hline SD NEGERI 031 & 66.7 & baik \\
\hline
\end{tabular}

Tabel 5. fungsi pengarahan

Pemaparan tabel menyatakan bahwa pada sekolah dasar negeri 024 mendapatkan niai sangat baik berdasarkan rincian pernyataan pada fungsi pengarahan yaitu kesiapan sebelum diadakannya pengaahan, melakukan evaluas setiap kegiatan pada cenang poin 4, kecuali pada pernyataan pengurus merencanakan pengarahn terhadap semua komponen pada poin 3. kemudian pada sekolah dasar 006 pada pernyataan pengurus merencanakan pengaahan, persiapan pengrahan dan evaluasi kegiatan centangan pada kategori kadang-kadang $(\mathrm{K})$.

\begin{tabular}{|l|l|l|}
\hline Nama Sekolah & Presentase & Nilai \\
\hline SD NEGERI 024 & 90.0 & sangat baik \\
\hline SD NEGERI 006 & 90.0 & sangat baik \\
\hline SD NEGERI 032 & 75.0 & baik \\
\hline SD NEGERI 016 & 60.0 & baik \\
\hline SD NEGERI 036 & 65.0 & baik \\
\hline SD NEGERI 023 & 90.0 & sangat baik \\
\hline SD NEGERI 031 & 75.0 & baik \\
\hline
\end{tabular}

Tabel 6. fungsi pengkoordinasian

Dipublikasikan Oleh :

UPT Publikasi dan Pengelolaan Jurnal

Universitas Islam Kalimantan Muhammad Arsyad Al-Banjari Banjarmasin 
Terdapat beberapa pernyataan terendah pada sekolah dasar negeri 016 yaitu sekolah memberikan wewenang pengurus secara penuh, pengurus mengetahui dan mengawasi dalam setiap kegiatan ektrakurikuler poin 3, pengurus membut job desk, membagikan job desk, menciptakan produktivitas kerja mendapatkan poin centang 2. kemudian pada seolah dasar negeri 036 fungsi pengkoordinasian pada aspek mengutamakan mekanisme kerja, memberikn wewenang pengurus secara penuh, mengetahui dan mengawasi kegatn ekstrakurikuler mendapatkan poin 3. serta pada aspek membuat dan membagikan job desk pada poin 2.

\begin{tabular}{|l|l|l|}
\hline Nama Sekolah & Presentase & Nilai \\
\hline SD NEGERI 024 & 50.0 & cukup \\
\hline SD NEGERI 006 & 68.7 & baik \\
\hline SD NEGERI 032 & 62.5 & baik \\
\hline SD NEGERI 016 & 43.7 & kurang \\
\hline SD NEGERI 036 & 68.7 & baik \\
\hline SD NEGERI 023 & 100.0 & sangat baik \\
\hline SD NEGERI 031 & 50.0 & cukup \\
\hline \multicolumn{2}{|c|}{ Tabel 7. fungsi penganggaran } \\
\hline
\end{tabular}

Terdapat nilai tertinggi yang diperoleh sekolah dasar negeri 023 pada aspek pengurus mencatat pemasukan dan menganggarkan pengeluaran, biaya pelatih, analisa budgetting pada kategori selalu (S), namun pada sekolah dasar negeri 016 nilai kurang dari hasil pernyataan yag dicentang mencatat pemasukan dan pegeluaran tidak pernah (TP) dilakukan dn pengurus menganggarkan biaya pelatih hasil centang sering (SR) serta analisa budgetting hasil centang kadang-kadang $(\mathrm{K})$.

\begin{tabular}{|l|l|l|}
\hline Nama Sekolah & Presentase & Nilai \\
\hline SD NEGERI 024 & 100.0 & sangat baik \\
\hline SD NEGERI 006 & 68.7 & baik \\
\hline SD NEGERI 032 & 68.7 & baik \\
\hline SD NEGERI 016 & 62.5 & baik \\
\hline SD NEGERI 036 & 62.5 & baik \\
\hline SD NEGERI 023 & 100.0 & sangat baik \\
\hline SD NEGERI 031 & 68.7 & baik \\
\hline
\end{tabular}

Tabel 8. fungsi penyusunan laporan

pada sekolah dasar negeri 024 dan sekolah dasar negeri 023 mendominasi dengan selalu menyusun laporan pada aspek melaporkan hasil, analisa terhadap kendala-kendala, laporkan seluruh kegiatan, dan membuat laporan jangka waktu tertentu dengan mendapatkan poin 4 kesluruhan sedangkan pada sekolah dasar 016 dan 036 pada pernyataan pelatih melaporkan hasil dan pengurus melaporkan semua kegiatan pada poin 3 serta melakukan analisa kendala dan laporan pendanaan jangka waku tertentu pada poin 2 sekolah dasar 016, namun pada sekolah dasar 036 membuat laporan jangka waktu tertentu dan pelatih melaporkan hasil pada poin 2 serta pada aspek pegurus meakukan analisa terhadap kendala-kendala dalam kegiatan ektrakurikuler dan pengurus melaporkan semua kegiatan ekstrakurikuler terdapat pada centangan poin 3. pada kegiatan ini perlu adanya evaluasi survei kembali dalam mengelola kegiatan ekstrakurikuler olahraga sesuai bidang yang diminati siswa dan acuan perencanaan kegiatan selanjutnya sesuai pernyataan Prasetyo (2013)

\section{PENUTUP}

Berdasarkan hasil penelitian dengan tujuan ingin mengetahui pengelolaan kegiatan ekstrakurikuler sekolah dasar di kota tarakan dari zonasi gugus terdapat beberapa masukan bahwa sekolah dasar negeri 023 dan 024 pengeloaan ekstrakurikuler yang dilaksanakan sangat baik dan dapat menjadi piloting projek untuk sekolah imbas, untuk sekolah dasar kategori baik berdasarkan hasil pernyataan terdapat pada sekolah dasar negeri 006, 031, 032 dan 036. berbeda dengan sekolah dasar 016 yang masih sangat minim pelaksanaannya sehingga

Dipublikasikan Oleh :

UPT Publikasi dan Pengelolaan Jurnal

Universitas Islam Kalimantan Muhammad Arsyad Al-Banjari Banjarmasin 
kategori cukup. Demikian hasil yang telah dilaksanakan dan dipaparkan ini dapat menjadi gambaran bagi warga sekolah yang telah di survei khususnya dan sekolah yang belum tersurvei pada umumnya untuk kedepannya pernyataan terlaksana semua dan apa sajayang perlu untuk ditingkatkan.

\section{REFERENSI}

Buku 1 Penulis

Eny Tarbiyatun Sayidah, Budi Sutrisno dan, \& Narimo, S. (2014). Pengelolaan ekstrakurikuler di sekolah menengah kejuruan negeri 4 klaten. 1-13.

\section{Buku 2 Penulis}

Tarbiyah, F., Keguruan, D. A. N., Ar-raniry, U. I. N., \& Aceh, D. B. (2019). PEMBINAAN PRESTASI NON AKADEMIK SISWA.

\section{Artikel Jurnal / Ensiklopedi}

Al Wahid, S. M., \& Prayoga, H. D. (2019). PENINGKATAN KETERAMPILAN MEMBERI UMPAN BALIK GURU PENDIDIKAN JASMANI OLAHRAGA DAN KESEHATAN (STUDI PADA GURU PENDIDIKAN

JASMANI OLAHRAGA DAN KESEHATAN). Riyadhoh: Jurnal Pendidikan Olahraga, 1(1), 5-9.

Bangun, S. Y. (2019). Peran Pelatih Olahraga Ekstrakurikuler Dalam Mengembangkan Bakat Dan Minat Olahraga Pada Peserta Didik. Jurnal Prestasi, 2(4), 29-37.

Nurcahyo, F. (2013). Pengelolaan Dan Pengembangan Kegiatan Ekstrakurikuler Olahraga Di SMA/MAN/Sederajat Se-Kabupaten Sleman. Jurnal Pendidikan Jasmani Indonesia, 9(2), 101-110. https://journal.uny.ac.id/index.php/jpji/article/view/3012/2505.

Prastyo, H. (2013). Survei pelaksanaan kegiatan ekstrakurikuler olahraga pada sekolah dasar negeri di Kecamatan Ngargoyoso Kabupaten Karanganyar tahun 2013 (Doctoral dissertation, Universitas Negeri Semarang).

Wandi, S. (2013). Pembinaan Prestasi Ekstrakurikuler Olahraga di SMA Karangturi Kota Semarang. ACTIVE: Journal of Physical Education, Sport, Health and Recreation, 2(8).

\section{Skripsi/Tesis/Disertasi dari Sumber Online}

Di, S., \& Menengah, S. (2016). Belajar 03.

Maulidiyah, I. (2014). Mengembangkan Sekolah Berwawasan Lingkungan Di Sma 3 Annuqayah. Tesis, 12710010

Dipublikasikan Oleh :

UPT Publikasi dan Pengelolaan Jurnal

Universitas Islam Kalimantan Muhammad Arsyad Al-Banjari Banjarmasin 